\title{
Preparation of Thematic Maps and Farming Situation Characterisation of Distributary Command Area using RS and GIS Techniques
}

\author{
Sourabh Singh Yadav*, Vivek Mishra, Vasu Kumar, Sunita Sahu, \\ Suraj Kumar and Prafull Katre \\ Department of Soil and Water Engineering, SVCAET \& RS, Indira Gandhi Krishi \\ Vishwavidyalya, Raipur (C.G), India \\ *Corresponding author
}

\section{A B S T R A C T}

Keywords

GIS, LISS IV, Command Area, DEM, FCC

\section{Article Info}

Accepted:

08 January 2020

Available Online:

10 February 2020
This paper reflects the use of newer technologies Remote Sensing (RS) and Geographical Information System (GIS) which play important role in monitoring canal water distribution and its management, cropping pattern identification and geomorphology characterisation of command area. The conjunctive use of surface and groundwater resources aims to harness maximum quantity of water to achieve optimal utilization of total water resources in a canal command area for maximum agricultural productivity. The command area of distributary no.21is situated in Arang block of Raipur district and located between $21^{\circ} 00^{\prime} 00^{\prime \prime}$ and $21^{\circ} 15^{\prime} 00^{\prime \prime} \mathrm{N}$ latitudes and $81^{\circ} 45^{\prime} 00^{\prime \prime}$ and $82^{\circ} 00^{\prime} 00^{\prime \prime} \mathrm{E}$ longitudes with $311 \mathrm{~m}$ to $262 \mathrm{~m}$ above mean sea level. False colour composite (FCC) of IRS-P6 LISS IV geocoded data and survey of India (SOI) toposheet on (1:50000) scale were studied in conjunction to extract various information of the distributary command area. Existing land use/land cover, slope, relief aspect, and physiography for characterization and soil texture map was prepared using the data collected and interaction with farmers of study area.Based on the preparation and overlaying of various thematic maps, along with analysis of Agrometeorological, Hydrological \& Geomorphological data, four farming situation, as per the local names of soil texture type viz. Bhata,Matasi, Dorsa, Kanhar were identified, characterized and mapped based on the soil sampling analysis and peoples participating research interaction of the village. It was found that command area is drained by network of two main streams, Sakti Nala and Shangari Nala; and paddy was cultivated on $98 \%$ area of command area.

\section{Introduction}

Water is elixir for life and the most precious gift of nature.Over utilization of surface water of the canal commands, have given rise to deleterious effects, such as (1) water logging, (2) salinization /alkalinization of the soils causing land degradation and decline in crop productivity and (3) deficit water supply at the tail ends of the command area. In the canal command areas, the available water is not sufficient to meet the requirement for all purpose. GIS is a collection of computer hardware and software, data and skilled 
personnel for managing and analyzing geographic data (Maguire et al., 1991). GIS has the capability to manage many layers, integrate and analyze spatial data from different sources, with diverse formats, structures, projections and helps in spatial modeling (Goodchild, 1992).

Naidu and Giridhar (2011) employed GIS for Geo-Spatial Database Creation for Wazirabad Canal Command Area. GIS based system can help to analyze the spatial information about its engineers and farmers to improve planning, management and supply of water resources in command area.

Therefore,high resolution remotely sensed data provides valuable and up-to-date spatial information on natural resources and physical terrain parameters. Geographical Information System (GIS) with its capability of integration and analysis of spatial, aspatial, multi-layered information obtained in a wide variety of formats both from remote sensing and other conventional sources has proved to be an effective tool in planning for canal command development programmes.

\section{Materials and Methods}

\section{Description of study area}

The study area is a part of command area of Distributary No. 21 of Rudri Barrage Left Main Canal (Mahanadi Main Canal) and its geographic location lies between $81^{\circ} 45^{\prime}, 00^{\prime}$, to $82^{\circ} 00^{\prime} 30^{\prime \prime}$ E longitude and $21^{\circ} 00^{\prime} 00^{\prime \prime}$ 'to $21^{\circ} 15^{\prime} 00^{\prime}$ ' $\mathrm{N}$ latitude in Raipur district of Chhattisgarh as shown in Fig. 3.1. Gross commanded area (GCA) of Distributary No.21 was 4863.15ha and culturable command area(CCA) was 3208 ha.

The Distributary no. 21 which servers the study area originates from Mahanadi Main canal. It flows through the nine villages of
Arang block namely Lakholi, Rasni, Kukra, Baihar, Orka, Arang, Ghumrabhata,Kalai and Borid. The general elevation of the area ranges from 262 to $311 \mathrm{~m}$ above mean sea level (MSL). It falls in SOI topographical map no. F44 P16 on scale- 1: 50,000.The annual average rainfall of the area is 1317.36 mm (2007-2016).

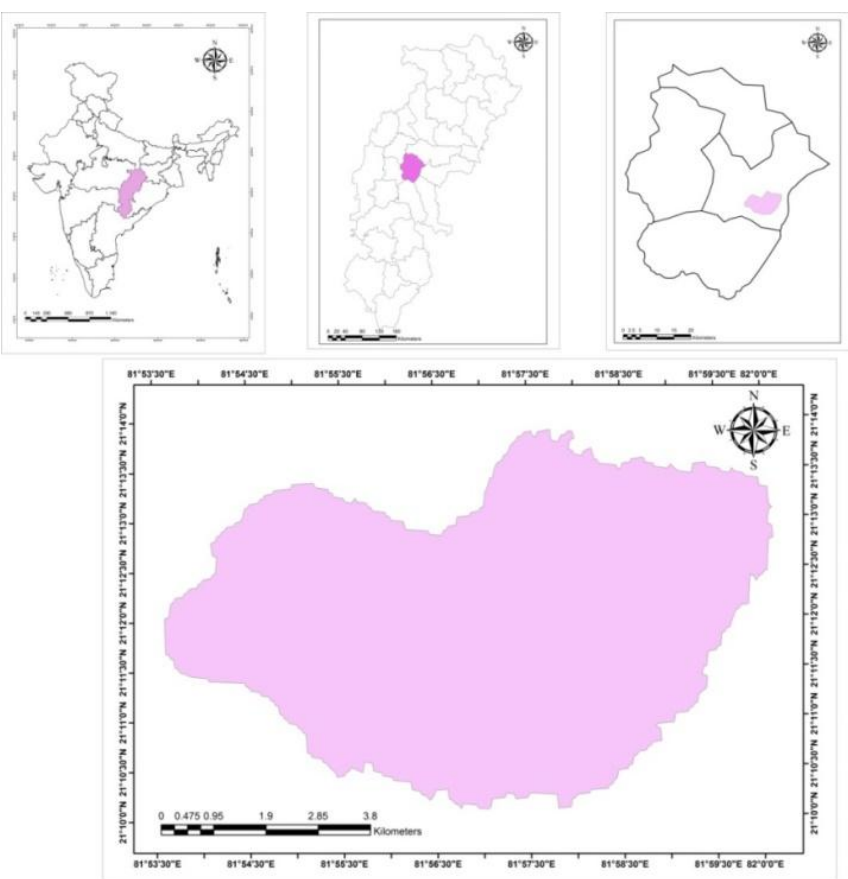

Figure.1 Location of study area

\section{Data collection}

Distributary No. 21 command area is covered by topographic map No. F44 P16 (64G/16) of $1: 50,000$ scale having $10 \mathrm{~m}$ contour interval, were collected from Survey of India, Raipur, Chhattisgarh.

The cloud free digital data of the study area were obtained from National Remote Sensing Centre (NRSC), Hyderabad in Compact Disc (CD). The satellite data were in four electromagnetic spectral bands (band 2: 0.45$0.52 \mu \mathrm{m}$, band 3: $0.52-0.59 \mu \mathrm{m}$, band 4: $0.62-$ $0.68 \mu \mathrm{m}$ and band 5: 0.77-0.86 $\mu \mathrm{m})$. Its sensor provided the data of $5.8 \mathrm{~m} \times 5.8 \mathrm{~m}$ spatial resolution. 
Table.1 Details of satellite image used in the study

\begin{tabular}{|c|c|c|c|c|c|c|}
\hline Topo sheet & Satellite & Sensor & $\begin{array}{c}\text { Resolution } \\
(\mathrm{m})\end{array}$ & Path & Row & Date of pass \\
\hline F44 P16 & IRSP6 & LISS IV & 5.8 & 102 & 58 & $23 / 10 / 2016$ \\
\hline
\end{tabular}

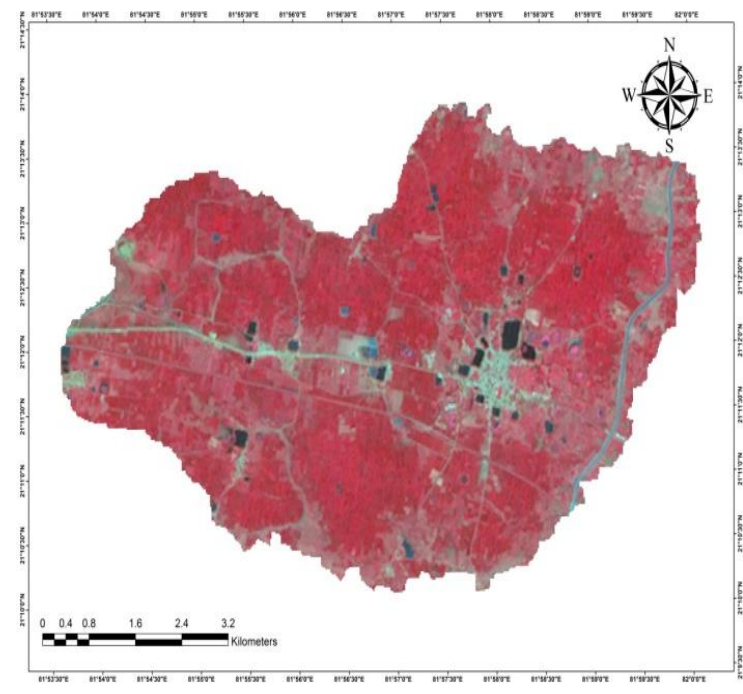

Figure.2 Standard FCC image of study area

Soil texture map of the distributary command area was prepared using Participatory Rural Appraisal (PRA) technique of soil survey and soil data from RAEO.

The area is characterized under Chhattisgarh plains Agro climatic zone .The data on crops acquired from the office of RAEO, Arang block and were processed to find out the existing land use and cropping pattern in the study area.

\section{Data processing}

All the required software were available in the Geo-Informatics lab of Soil and Water Engineering Department, IGKV, Raipur, such as ArcGIS 10.4 for digital data analysis and ERDAS IMAGINE 11 for image processing.

Topographic mapsF44 P16 with the scale of 1:50000 was scanned and scanned map was registered with respect to grid base using ERDAS IMAGINE 11 software in order to have real world coordinates through Georeferencing process.

Various maps such as contour map, soil map and command area boundary were digitized in ArcGIS 10 and information available with each map was entered as an attribute value in GIS to prepare the database of a particular thematic map.

\section{Preparation of thematic maps}

\section{Boundary of distributary command area}

The boundary of distributary command area is prepared manually using topographic map having $10 \mathrm{~m}$ contour map, drainage network of the study area and the distributary map obtained from CGWRD on the ArcGIS platform.

\section{Preparation of drainage map}

Drainage map comprises of various streams that are flowing in the area. Drainage patterns and textures are key signatures and very important terrain recognition elements, used as criteria for identification of geological and geomorphological phenomena.

\section{Generation of DEM}

A DEM is a numerical representation of landscape topography. DEM is the digital representation of the topographic surface. DEM was prepared using contour lines and elevation points extracted from SOI toposheets and additional attributes observed from GPS. 


\section{Generation of contour map}

The contour map of the study area was drawn with the help of the toposheets and DEM. The contours were drawn at 10 meter intervals.

\section{Generation of slope map}

The slope map was prepared from DEM and contour map. 3D analyst tool is then used to convert digitized contours into Triangulated Irregular Network (TIN) model and then to DEM. From this DEM, slope map was generated using this process: Arc GIS 3D Analyst tool Surface analysis Slope Percentage function.

\section{Soil texture map}

The soil texture was the only physical property that was analyzed in laboratory.The soil texture of the study area was calculated by using International Pipette method; map was prepared using Arc GIS 10.

\section{Land use/land cover classification}

The ERDAS IMAGINE 11 software has been used for land use/cover classification in this study. Most common land use classification method "supervised classification" also known as pixel based classification was used in this study.

Maximum Likelihood Classifier (MLC) module was used for classifying the land uses. The False Colour Composite of the year 2016 is used for land use/cover classification in this study.

\section{Results and Discussion}

\section{Generation of base map}

A Base map is the frame to which all ancillary data will be registered. The base map is prepared using Survey of India Toposheet F44 P16 on 1:50000 scale. The map, thus, drawn is scanned and digitized to get a digital output. Command area of Distributary No. 21 was used for this study.

\section{Preparation of thematic map}

On the basis of standard methodologies described in materials and methods, following given maps have been prepared.

\section{Boundary of distributary no. 21}

The geographical area of the Distributary No. 21 is 4863.15 ha. The boundaries were digitized as described previously .The maps of Boundary of Distributary No. 21 are shown in Figure 3.

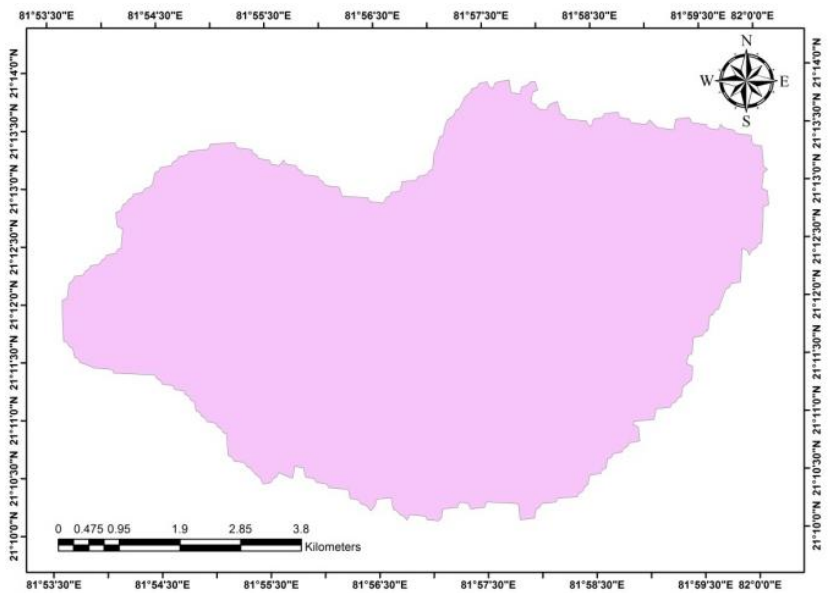

Figure.3 Boundary of Distributary No. 21

\section{Distributary network map}

The Distributary No. 21 consists of 6 minor namely Borid minor, Rasni-Kukra minor, Arang minor 1, Arang minor 2, Odka-Baihar minor and Rasni Baihar minor.

Each minor is named after the village it irrigates. The Distributary Network Map the command area is shown in Figure 4. 


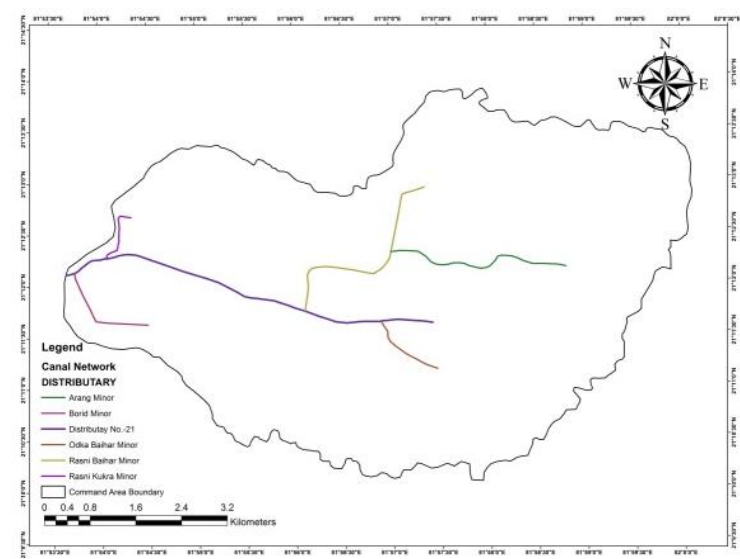

Figure.4 Distributary Network map

\section{Drainage map of distributary command area}

Drainage map was prepared by using Survey of India Topographic maps on 1:50,000 followed by further modification in ArcGIS using Spatial Analyst Tools. All the streams existing in this command area and their order are marked in Figure5. The entire area of the command area is drained by two main streams, Sakti Nala and Sanghari Nala.

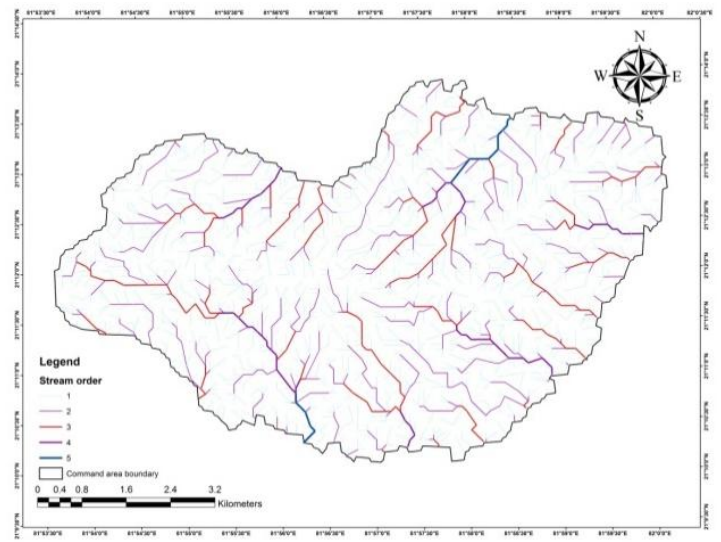

Figure.5 Drainage map distributary command area

\section{DEM of distributary command area}

DEM is the digital representation of the topographic surface. DEM was prepared using contour lines and elevation points extracted from SOI toposheets and additional attributes observed from GPS in the study watershed. Figure6 shows the DEM of the study area. Different colours give different zones of interpolation. The accuracy of results obtained from a DEM depends on the recent topography or contours and resolution. The DEM was prepared from the contours traced from the topographic sheet.

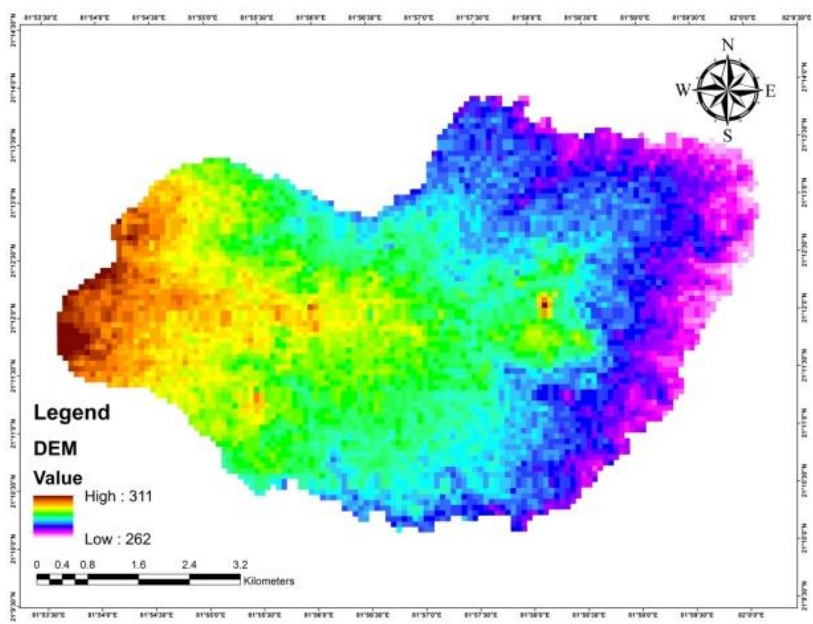

Figure.6 DEM of distributary command area

\section{Contour map of distributary command} area

The Contour Map was generated through GIS Digital Elevation Model (DEM) of $30 \mathrm{~m}$ by $30 \mathrm{~m}$ resolution of the study area. Figure 7 shows the Contour Map of the study area.

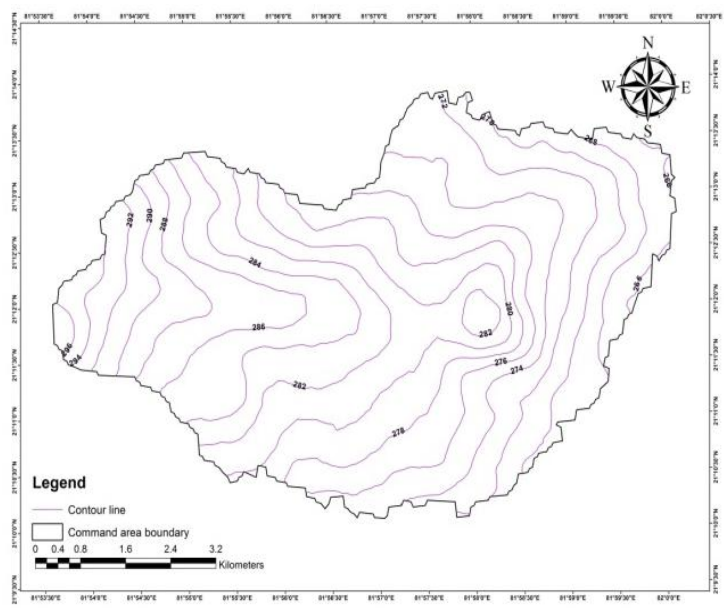

Figure.7 Contour Map of distributary command area 
Table.2 Slope categories

\begin{tabular}{|l|l|l|}
\hline Class & Percentage $(\%)$ & Slope Category \\
\hline I & $0-1$ & Nearly level \\
\hline II & $1-2$ & Very gentle sloping \\
\hline III & $2-5$ & Gently sloping \\
\hline IV & $5-10$ & Moderately sloping \\
\hline V & $10-12$ & Strongly sloping \\
\hline
\end{tabular}

\section{Slope map of distributary command area}

The slope values can be measured either in percentage or degrees. The slope map (Figure8) was prepared using the contour information of survey of India topographical maps on 1:50000 scales with 10-meter contour interval and further worked in ArcGIS to generate the slope map. The different classes of slopes corresponding to their percentages were categorized in Table 2.

The slope information is useful in understanding the topography, geomorphology soil types and their erodibility, surface drainage. Slope is a vital for land capability assessment, formulating soil and water conservation measure.

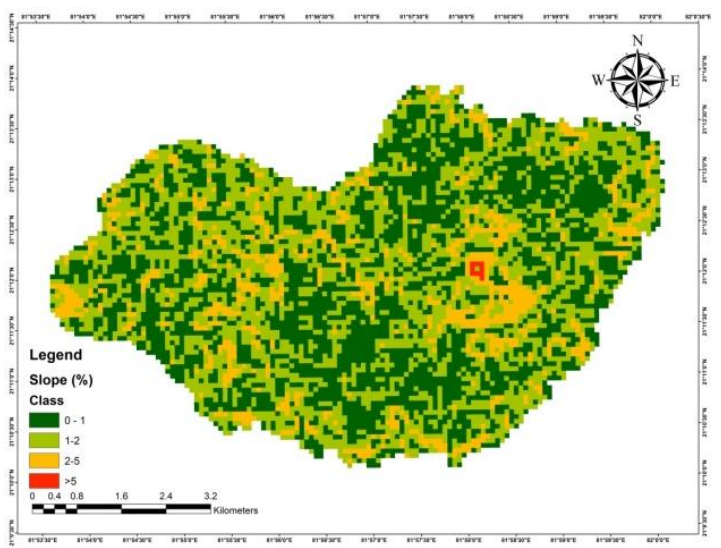

Figure.8 Slope map of distributary command area

\section{Land use/cover map of the distributary command area}

The NRSC Data Centre, Hyderabad provided the cloud free geocoded digital data of IRSR2 (LISS-IV) in CD ROM. The imagery, which covers the distributary command area, was used in the study. Pixel based classification technique was used to classify the land under Five Class.

Area under different land use classes obtained after classification are given in the Table No. 3 and Fig. 9.The results showed that there were 5 land use classes in the watershed with major part of the study area is dominated by Lowland Paddy (1557.48 ha) which is $32.03 \%$ of the total area.

This is followed by current fallow (1232.27ha) which is $25.34 \%$ and Midland Paddy (1138.59 ha) which is $23.41 \%$ of the total area.Settlement occupies 780.13 ha which is $16.04 \%$ of the total area.

Water body contributes $3.18 \%$ of the total area. Distributary command area is mainly single cropped and paddy is the major crop during kharif season. 
Table.3 Land Resources use pattern of small watershed

\begin{tabular}{|c|c|c|c|}
\hline Value & Land use & Area (ha) & $\begin{array}{c}\text { Area in } \\
\text { Percent(\%) }\end{array}$ \\
\hline $\mathbf{1}$ & Water Body & 154.67 & 3.18 \\
\hline $\mathbf{2}$ & Current Fallow & 1232.27 & 25.34 \\
\hline $\mathbf{3}$ & Lowland paddy & 1557.48 & 32.03 \\
\hline $\mathbf{4}$ & Midland paddy & 1138.59 & 23.41 \\
\hline $\mathbf{5}$ & Settlement & 780.13 & 16.04 \\
\hline & Total & 4863.15 & 100.00 \\
\hline
\end{tabular}

Table.4 Area under different soil texture

\begin{tabular}{|l|c|c|c|c|}
\hline \multicolumn{1}{|c|}{ Village Name } & \multicolumn{4}{|c|}{ Type Of Soil } \\
\cline { 2 - 5 } & Bhata(ha) & Matasi(ha) & Dorsa(ha) & Kanhar(ha) \\
\hline Arang & 202 & 216 & 229 & 1251 \\
\hline Baihar & 0 & 27.88 & 83.64 & 167.28 \\
\hline Borid & 0 & 0 & 0 & 560.3 \\
\hline Ghumrabhata & 0 & 0 & 56.4 & 84.6 \\
\hline Kalai & 0 & 9.6 & 44.8 & 120.78 \\
\hline Kukra & 0 & 155.6 & 99.3 & 191.5 \\
\hline Lakholi & 10 & 169 & 105 & 185 \\
\hline Orka & 0 & 0 & 0 & 174.4 \\
\hline Rasni & 0 & 72.01 & 216.02 & 432.04 \\
\hline Total & 212 & 650.09 & 834.16 & 3166.9 \\
\hline Percentage (\%) & 4.35 & 13.37 & 17.17 & 65.12 \\
\hline
\end{tabular}

\section{Farming situation ( soil texture)}

The soil texture was the only physical property that was analysed in laboratory.Four farming situation, as per the local names of soil texture type viz. Bhata,Matasi, Dorsa, Kanhar were identified, characterized and mapped based on the soil sampling analysis and peoples participating research interaction of the village.
The predominant textures of the soil profiles in the entire study area were found to be Vertisols (kanhar) contribute 9992.178 ha, which is $65.12 \%$ of the total area, followed by Alfisol(dorsa) 834.16 ha, Inceptisols(matasi) 650.09 ha and Entisols(bhata) 212 ha as given in Table 4 and Fig. 10.Soil erosion depends much on the infiltration rate of a soil. The properties of soil in study area is given in Table No. 5. 
Table.5 Physio-chemical properties of soil of study area

\begin{tabular}{|l|l|l|l|l|}
\hline Partiulars & Bhata & Matasi & Dorsa & Kanhar \\
\hline Soil depth(cm) & $5-25$ & $25-75$ & $75-100$ & $>100$ \\
\hline Sand (\%) & $50-75$ & $30-55$ & $20-35$ & $15-30$ \\
\hline Silt $(\%)$ & $15-30$ & $30-55$ & $25-35$ & $20-35$ \\
\hline Clay (\%) & $10-25$ & $20-40$ & $34-50$ & $45-50$ \\
\hline Bulk density(g/cc) & $1.75-1.85$ & $1.56-1.66$ & $1.36-1.66$ & $1.29-30$ \\
\hline pH & $5.5-6.5$ & $6.4-7.0$ & $7.0-7.5$ & $7.4-7.7$ \\
\hline Infiltration (cm/hr) & $4.1-6$ & $0.5-2.9$ & $1.30-1.60$ & $1.3-1.35$ \\
\hline $\begin{array}{l}\text { Available } \\
\text { water(cm/m) }\end{array}$ & 2.2 & 8.8 & 17.5 & 17 \\
\hline
\end{tabular}

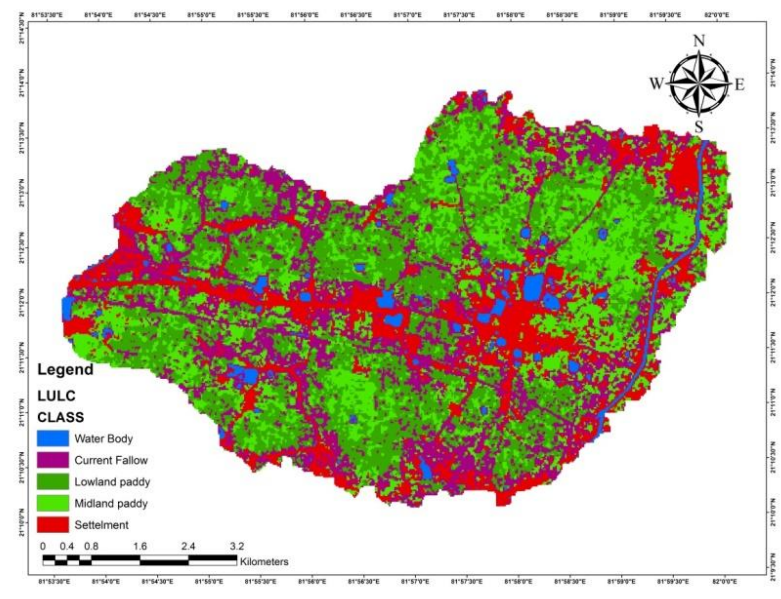

Figure.9 Land use/cover map of distributary command area

In the present study, GIS has been extensively used in determination of geomorphological parameters of the command area. The command area has sufficient potential to meet the ever increasing demand of water if harvest and conserve properly. Statistics on farming situation of the study area has already revealed that a significant portion of the fallow land can be brought under cultivation if proper water and land management practices are performed. In the present study, GIS has been extensively used in determination of geomorphological parameters of the command area. GIS can

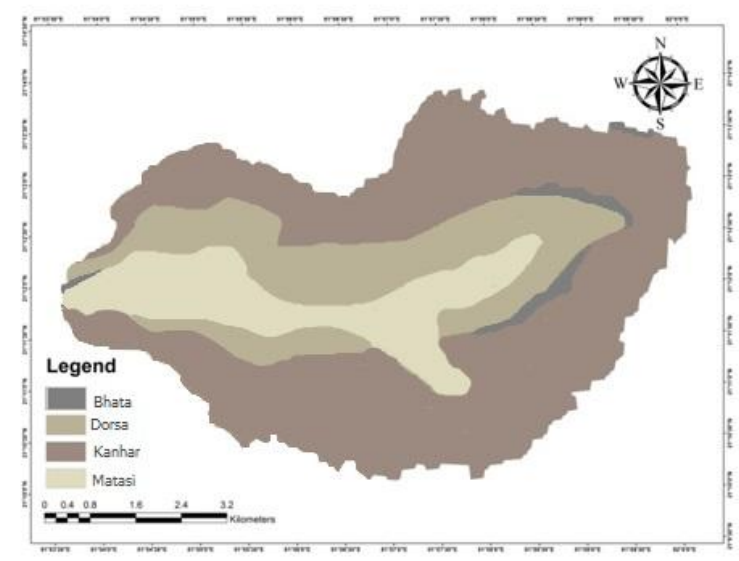

Figure.10 Soil Texture map of distributary command area

handle a large amount of spatial and nonspatial data (Ramkrishnan, et al., 2009). The integration of Remote Sensing and GIS along with field data provides an appropriate approach for solving various resources management problems.

\section{References}

Chakraborti, A.K. (1993). Strategies for watershed management planning using remote sensing techniques. J. of Indian Soc. of Remote SensingPhotonirvachak, Vol. 1(2): 87-98. 
El-Sayed, S.M. and Roushdy, M.T.; Study of El-Zomor Canal improvement using geographical Information systems; Hydraulics Research Institute, report no. 172, 2005.

Goodchild, M. F., 1992. Geographical information science. International Journal of Geographical Information Systems 6(1): 31-45.

Govindaraj, R., Dhas, D.V. and Kumar, N. A. 2013.Micro level agricultural information system using GIS.Published in: (Geospatial World Weekly 6 May 2013).

Hiese, N., Mich, N., Yanthan, M., Yeptho, H., Moatoshi, Lotha, R., Pienyü, K., Suokhrie, S., Murry, B. and Mor, S. 2011. Application of Geoinformatics in Land Resource Management at MicroWatershed level for sustainable development of Sanis, Wokha District, Nagaland. Dimension and direction of geospatial industry. Geospatial world forum 18-21, January Hyderabad.

Janssen, R. and Rietveld, P. (1990) "Multicriteria analysis and geographical information systems: An application to agricultural land use in the Netherlands", Geoj. Lib., pp. 129-139.

Maguire, D. J., Goodchild, M. F. and Rhind, D. W., 1991. Geographical Information Systems: Principles and Applications, Vol. II. John Wiley \& Sons, New Work. Manchanda, M. L,. Kudrat, M. And Tiwaria.K. 2002. Soil Survey and Mapping Using Remote Sensing. Tropical Ecology 43(1): 61-74

Mukeshkant, Singh P R, Singh, A. K., and Kumar, Dilip 2015 Study of Dighora
Micro watershed, Chhattisgarh Through Remote Sensing \& GIS. International Journal of Remote Sensing \& Geoscience :37-40.

Naidu, C. R. and Giridhar, M. V., 2011. GeoSpatial Database Creation for Wazirabad Canal Command Area. Geographical Information Systems, 3(4): 290-297.

Patil. N.P., Kadale, A.S., Mhetre, G.S. 2015. Assessment of Morphometric Characteristics of Karwadi-Nandapur Micro Watershed Using Remote Sensing And Geographical Information System. International Journal of Scientific \& Technology Research Volume 4(4): 175-179.

Paul, J. C., Mishra, J. N. Pradhan, P. L. and Sharma, S. D. 2008. Remote Sensing and GIS Aided Land and Water Management Plan Preparation of Watershed - A Case Study. Journal of Agricultural Engineering. 45(3): 27-33.

Rokade, V.M., Kundal ,R and Joshi A.K. 2004. Water Resources Development Action Plan Sasti Watershed, Chandrapur District, Maharashtra Using Remote Sensing And Geographic Information System. Journal of the Indian Society of Remote Sensing, 32(4): 363-372.

Solanke, P., C., Shrivastava, R., Prasad, J., N., Saxsena, R.K. and Barthwal A.K. 2005. Application of Remote Sensing and GIS in Watershed Characterization and Management

Voogd H. (1983) Multicriteria evaluation for urban and regional planning, Pion Ltd.

\section{How to cite this article:}

Sourabh Singh Yadav, Vivek Mishra, Vasu Kumar, Sunita Sahu, Suraj Kumar and Prafull Katre. 2020. Preparation of Thematic Maps and Farming Situation Characterisation of Distributary Command Area using RS and GIS Techniques. Int.J.Curr.Microbiol.App.Sci. 9(02): 992-1000. doi: https://doi.org/10.20546/ijcmas.2020.902.116 